\title{
Temtamy Syndrome
}

National Cancer Institute

\section{Source}

National Cancer Institute. Temtamy Syndrome. NCI Thesaurus. Code C148371.

An extremely rare autosomal recessive condition caused by mutation(s) in the C12orf57 gene, encoding protein C10. It is characterized by agenesis/hypoplasia of the corpus callosum, associated with developmental delay, and variable craniofacial and skeletal abnormalities. 